\title{
VTCN1 Gene
}

National Cancer Institute

\section{Source}

National Cancer Institute. VT CN1 Gene. NCI Thesaurus. Code C106221.

This gene plays a role in the regulation of cell-mediated immunity. 